\title{
Producing Knowledge, Producing Credibility: British Think-Tank Researchers and the Construction of Policy Reports
}

\author{
Jordan Soukias Tchilingirian ${ }^{1}$
}

Published online: 3 April 2018

(C) The Author(s) 2018

\begin{abstract}
Think-tanks and their researchers are located within an interstitial and ill-defined 'space between fields'; a space both constituted and divided by the worlds of academia, politics, journalism and business. This liminal position can be problematic for a think-tank researcher's intellectual credibility as they lack the recognised cultural and symbolic capital derived from being located within an established profession's jurisdiction. The question arises, how do think-tanks gain intellectual credibility? Drawing on interviews with think-tank researchers, this paper explores how these interstitial intellectuals produce policy reports. In following this process, we find that credibility emerges from a complex web of relationships across established fields/professions. Think-tank researchers must engage in a complex 'dance' of positioning the symbols, capitals and interests of a number of professions. To maintain their integrity, researchers must try to keep in step with competing interests from different professions; at times aligning them, at other times blocking or obscuring them from one another.
\end{abstract}

Keywords Think-tanks $\cdot$ Credibility $\cdot$ Knowledge production $\cdot$ Policy research

For the last three decades, researchers focussing on knowledge production have noted significant transformations in the way research is conducted, and the manner in which intellectuals relate to wider society. Of the various theories that chart changing science systems, the works of Michael Gibbons and Helga Nowotny et al. (Gibbons et al. 1994; Nowotny et al. 2001, 2003) have gained considerable interest. ${ }^{1}$ According to the Gibbons-Nowotny thesis, earlier stages of modernity were characterised by a predominant means of knowledge production referred to as 'Mode 1'. This mode of knowledge production occurs within relatively autonomous and hierarchically

${ }^{1}$ See Hessels and van Lente (2008) for a critical review and account of the wider research

Jordan Soukias Tchilingirian

j.s.tchilingirian@bath.ac.uk

1 Department of Social and Policy Sciences, University of Bath, Bath, UK 
structured fields - housed inside universities - and practiced by intellectuals belonging to distinct disciplines (Stampnitzky 2013a, p. 12). When Mode 1 intellectuals communicate with wider society, they adopt a guru-like status, providing empirically verifiable solutions for institutions, especially governments (Osborne 2004, p. 433). These interventions are based on established and recognised disciplinary distinctions or professional credentials (Grundmann 2017, p. 27).

'Mode 2' knowledge production is associated with the onset of late modernity; it is characterised by knowledge production outside the traditional university, and the concomitant diversification of intellectual principles and practices (Gibbons et al. 1994, p. 3). Traditional sites of knowledge production still exist in a Mode 2 context (Gibbons et al. 1994, p. 11), but traditional coherent, bounded, and exclusive fields that are populated by attributed experts no longer hold the monopoly on expertise (Epstein 1995). Rather, claims to socially and politically relevant expertise - such as security analysis and terrorism studies increasingly take place at the intersection of a number professions and fields (Eyal and Pok 2015; Stampnitzky 2013a). These new sites can be conceptualised as liminal spaces between fields (Eyal 2011) — spaces between established disciplines which are shared by actors who claim to share similar forms of expertise, but who represent a variety of professions and organisations with differing goals, intentions, practices and judgements (Eyal 2002, p. 653).

The policy research and advocacy organisations known as think-tanks are one example of knowledge producing organisations which operate within such spaces, as they are located in an interstitial zone "at the crossroads of the academic, political, economic, and media" professions (Medvetz 2012, p. 42). Think-tanks are active across the globe and vary greatly between and within different polities (McGann 2017; Stone and Denham 2004; Stone et al. 1998). Some think-tanks display characteristics associated with universities (e.g. they employ numerous PhDs, and publish in peer reviewed journals); others function like social research consultancies, or are openly ideological and/or associated with specific political parties (Denham and Garnett 1998a; McGann and Sabatini 2011; Stone 1991; Weaver 1989).

Think-tanks produce policy advocacy and policy analysis; their output is in high demand and yet (because of their interstitial position) they are regularly criticised for being either too political, ideological, erudite or journalistic (Medvetz 2012). The question arises, how do these intellectuals construct knowledge which is seen to be policy relevant and credible? This paper answers this question by exploring how British think-tank researchers create policy papers, the most common intellectual output of think-tanks. What follows is an account of the way in which think-tank researchers engage with representatives from the multitude of professions within the policy nexus as they conduct policy research.

\section{Think-Tanks and Policy Intellectuals}

Think-tanks are often used to explain a historically significant episode or outcome in policy making or national politics. For example, British political science presents think-tanks as embedded within networks around political parties or cliques within these parties such as the 'Blairites' within the Labour Party (Bentham 2006; Pautz 2012) or the 'Cameronites' within the Conservative Party (Pautz 2013). Here the think-tank is a Gramscian organic intellectual of 
a specific political project. For those who study think-tanks from this perspective, the importance of think-tanks within these networks stems from their ability to monopolise the following three key functions.

First, think-tank intellectuals have the practical skills and networks to communicate to wider audiences and mobilise media opinion through branding, mediating, and selling ideas in the national press (Arnoldi 2007). Secondly, think-tanks can broker expert knowledge, selecting, editing, and transforming these ideas to build (or support existing) policy narratives (Ball and Exley 2010; Blank 2003; Stone 2007). Thirdly, they act as sites of 'ideological fellowship' (Denham and Garnett 1998b, p. 34), allowing intellectuals and other policy or political actors "to preserve the coherence of their views" (Desai 1994, p. 40) when their ideas are deemed beyond the pale of acceptable politics (Desai 1994; Harrison 1994). Thus, even with highly technical issues, think-tanks act as hubs - where social and emotional solidarity between specific actors from industry, academia, politics, and journalism can be built and maintained (Pautz 2012; Pirie 2012). Such analysis is useful in understanding how think-tanks are positioned and used by those within their networks of influence, but these studies bracket out the process by which knowledge is made and leave questions about credibility largely unexplored.

More investigative sociologists and journalists critically question the financial intellectual transparency and independence of think-tanks. In these studies, think-tank intellectuals work to propagate another group's (often corporate or right wing) interests (McClenaghan 2012; Miller and Dinan 2015; Ruane 2010). Similar to the position propounded by the power-structure research tradition (Burris 1992, 2008; Domhoff 2006), think-tanks are seen as "extensions of the corporate community in their origins, leadership, and goals" (Domhoff 2006, p. 72). The think-tank intellectual thus becomes a handmaiden for elite interests, lacking in cognitive autonomy and scholarly rigour. As such think-tanks lack real credibility, and their knowledge is illegitimate.

These studies align think-tanks with different poles within the field, which is a problematic approach for a number of reasons. First, these approaches tend to restrict their focus to certain types of think-tanks - either the more scholarly policy research institutes or policy-advocacy organisations - which narrows the definition of think-tanks. Attention then turns to a think-tank's connections to either the political, academic, or corporate worlds, thus binding a think-tank researcher's labour and expertise to another community's interests. As McLevey (2015, p. 273) argues, any elaborations upon intellectual life are framed through issues relating to the rigour or trustworthiness of think-tank expertise. Accounts of think-tank research are filtered through the simplistic images of the 'expert-cum-political advisor' or the 'elite puppet'. Neither image illuminates how these intellectuals assert or seek to demonstrate expertise and credibility.

\section{Approach}

\section{From Social Space to Trans-Professional Networks}

Rather than assuming that think-tanks and their researchers are dependent on one community and its dominant logic or interests, Thomas Medvetz (2012) offers a Bourdieuan inspired analysis of the space of think-tanks. Reflecting on American think-tanks, Medvetz charts the emergence of a semi-autonomous organisational space at the intersection of the fields of politics, academia, business, and the media. Think-tanks are symbolically and materially sustained by these four parental fields. Because the space of think-tanks is quadrisect and hybrid, it is 'field like' but far from distinct or mature. This 'hybrid' space influences the practices and motivation of think-tanks 
and their researchers; the social space and its corresponding habitus also become 'hybrid'. As actors within this interstitial space possess and cultivate differing capital profiles and positions from across four parental fields, their symbolic capitals are equally diverse.

The benefit of Medvetz's approach is that it respects the diversity which exists within the category of think-tank and succeeds in encompassing organisations with very different aims, strategies, and interests. It also pays appropriate attention to the ways in which differing think-tank professionals seek to reconcile their hybrid intellectual practice, by moving away from the assumption that a think-tank's labour-and its associated credibility-is simply an extension of a single field or profession. Medvetz moves towards a model which takes account of the structuring effects of the norms and practices of several professions. Medvetz (2010) suggests that the lifeworld of the think-tank researcher is like a 'vaudeville act'. This colourful metaphor draws attention to the way in which the policy researcher embodies a set of (imperfect and off balance) dispositions gleaned from a variety of established professions, which at once allows them to be a researcher, journalist, policy adviser and fundraiser. In sum, a think-tank researcher's intellectual credibility is the "attribute which persuades others to believe and invest in researchers and their ideas" (Smith 2010, p. 182). In this diverse social space, the credibility which underpins a think-tank intellectual's expertise is also hybrid.

Whilst Medvetz's approach is valuable, it betrays an established tendency within the sociology of knowledge - the assumption that intellectual life is led by a 'will to institutionalise' (Eyal and Pok 2015; Stampnitzky 2011, 2013a). By focussing on the capital profiles and structural relations of an intellectual 'field in the making', Medvetz - like Bourdieu—purifies the wider social world (Eyal and Pok 2011, pp. 16-17), excluding actors who do not self-define as think-tanks. This is problematic for an investigation of intellectual life and knowledge production, as wider relations of allies, collaborators, teams and opponents are overlooked (cf. Baert 2012; Collins 1998).

Moreover because the space is interstitial, a think-tank researcher's credibility and expertise cannot be located within one field or domain, nor can it simply be located within the relational space between think-tanks. Similarly, credibility is not an attribute of an individual intellectual or organisation (Eyal and Pok 2015). Instead, expertise and intellectual credibility within the hybrid and weakly institutionalised world emerges from a network connecting a variety of actors across the knowledge-policy nexus (Eyal 2013, p. 873; Stone 1996, pp. 132-133).

\section{Methods and Sample}

The findings presented are selected from a larger mixed method social network analysis of knowledge production within British think-tanks. Defining a think-tank is difficult; this poses problems when sampling organisations to research. Current directories are quite clearly bound up with the wider struggle of definitions. To mitigate this, and following Salas-Porras (2015), the sample was constructed through triangulating several data sources to establish an initial longlist of British think-tanks. ${ }^{2}$ The list

\footnotetext{
${ }^{2}$ The sources included: the 2011 Think-tank and Civil Societies directory maintained and updated by the University of Pennsylvania http://www.gotothinktank.com/directory/; profiles and lists generated by the British press organisations (e.g. Helm and Hope 2008; List of thinktanks in the UK. 2013, September 30); and lobbyists (Zetter 2008); Wikipedia lists https://en.wikipedia.org/wiki/List_of_think_tanks_in_the_United_Kingdom; as well as established studies and literature reviews.
} 
included 290 organisations of varying sizes, with diverse staff skills sets, organisational affiliations, research specialisms, and levels of public recognition. To enable meaningful comparisons whilst maintaining the diversity of the sample, think-tanks were sampled that engaged in contesting and producing knowledge for British social policy. This excluded organisations that:

- specialised only in environment, defence, international development, macroeconomics

- had an exclusively regional focus or an interest in a specific country within the United Kingdom in its research output

- defined themselves as a pressure group rather than a think-tank or policy research institute

- did not write specific policy reports, as opposed to other interventions such as blogs. However, organisations producing more essay-like policy papers were included.

This process created a shortlist of 29 organisations, which was then validated by various actors within the policy research world to ensure sample completeness (a form of member checking). Interviewees included 53 senior and junior research staff, and took place in London between 2012 and 2014. Analysis followed a broadly inductive analytical approach (akin to the constant comparative method) to derive specific themes which could be abstracted into more general accounts of the research process (Boeije 2002).

\section{Findings}

\section{The Three Dimensions of Credibility}

Every research project undertaken by a think-tank poses a potential threat to an individual's and organisation's credibility. The threat of losing credibility was often compared to a state of poor mental health. Interviewees would talk about the need to police their publications to avoid the risk of 'going bonkers' or generating ideas which are 'absolutely crazy'. The risk of 'madness' was contrasted with the need to be 'sensible' or 'credible'. Credibility can be lost through three interlinking activities:

- Becoming inconsistent with your organisation's stated aims/ethos, or public/historic perceptions of your aims/ethos

- Advocating ideas that are politically extreme; utopian and/or impractical; poorly researched, or missing vital information

- Producing research which is perceived to be funder led

It is important to note that the tensions that underpin intellectual credibility are relational. It is the interpretations of those who consume a think-tank's research that have the power to position the intellectual as credible or otherwise.

\section{Expertise and Brand}

Interviewees would often refer to their think-tank's particular organisational identity or brand when asked about what influences the content and aim of a policy report. As one free market think-tank director described, policy formulation was one part of their work, but it was more important to "[beat] the drum for free enterprise for market-led solutions". 
However, it is not just the classic ideologues of the New Right ${ }^{3}$ who fit this model. All think-tanks are positioned through this notion of rigidity (in the negative), or commitment to ideals (in the positive). For example, researchers from centrist and centre left think-tanks explained their own personal reasons for researching a topic as 'furthering social justice' or 'promoting social mobility'. Academic and contract research think-tank researchers would position their brand through an apolitical commitment to 'knowledge/science', method, and analysis. In many respects, the organisational brand can be seen as the first node in the creative network, as it is the researcher's interpretation of their organisations aims, goals and stated position (sometimes regulated by colleagues) which first shapes the design of the intervention.

Think-tanks differ in their flexibility or steadfastness to their brand and ideals. Flexibility and rigidity can be both positive and negative for the daily work of researchers and the long-term strategy of a think-tank. For some researchers, the fact that their think-tank has a distinct identity sediments the positions their organisation can take. As a researcher from a centre left think-tank explained, movements away from certain ideas can be problematic:

\section{Interviewer: Do people believe a repositioned think-tank?}

No and that is part of the problem.... If your position is core centre left and if you have big ideas like [names think-tank] always have, do not try to turn into something completely different! Go to an organisation that is amenable to that, or set up new ones. There is lots of scope for a change, but... if anyone came in saying that we were going to change our approach we would say you're being mad.

Being wedded to a certain standpoint or ideology does not mean dodging the 'realities' of contemporary politics - or that the think-tank is under less pressure to 'keep up' with policies and politics - but rather that they have a consistent brand, which means they are likely to have a place in the spectrum of opinion, policy advice, and debate. In some respects, the organisation's identity has a life and power of its own, above and beyond that of researchers and other staff members. As the director of a centre left think-tank explained, this is an ambivalent situation; brand somewhat constrains individual innovation, but also underscores and affirms the think-tanks expertise which can bring benefits.

We are seen as guardians of a tradition on welfare spending and certainly there were some discussions where it was almost expected of me, you know, that I would be the guardian of the state and in sort of playing that role of [advocating] the traditional values of the welfare state and things like that. It's like there was a [names think-tank] space hole in lots of the debates.

Although a think-tank's brand helps it make policy interventions, it anchors research to a certain position and stymies internal diversity of opinion. This means that even legitimate policy pronouncements can be viewed with scepticism, because they do not fit with the wider community's perceptions of the think-tank. Therefore, irrespective of their wishes, the

\footnotetext{
${ }^{3}$ In Britain the New Right refers to the ideological and political project associated with Thatcherism which favours a 'free market and strong state' (Gamble 1988). The key think-tanks associated with this movement include The Institute of Economic Affairs, Centre for Policy Studies, and the Adam Smith Institute (Denham 1996).
} 
researcher is always thinking in relation to their organisational brand, and a form of 'madness' is incongruity with that brand.

Interviewees were aware that the brand was already active in the public sphere before they joined; policy makers, journalists and potential funders all share this brand awareness. A think-tank brand is embedded in the norms and behaviours enacted in the everyday interactions (and possibly even resourcing decisions), between colleagues within the organisation, and internal structures support and maintain it. For example, one interviewee was personally motivated, and thus requested, to research arts funding at a local government level. Her director interpreted this as outside the organisation's key aims, and thus less worthwhile seeking funding for. Sometime later, having been promoted, the researcher was able to fundraise for and complete this project, emphasising its importance as a new avenue within the brand. This illustrates that brand is negotiated and interpreted within the organisation, and is influenced by the hierarchy; it frames decision-making when determining what is in and out.

\section{Networks as a Site of Opportunity}

All think-tank researchers noted that they have to remain consistent with their organisational brand; manage funder influence; and develop robust and relevant reports, but how they do so differs greatly between think-tanks and individual researchers.

Policy-advocacy think-tanks from across the political spectrum tend to be staffed by researchers with little to no official or credentialed expertise in a specific policy area. A recurring comment from more junior researchers was how little they knew about a policy area, or that their educational background was not related to the topic under investigation. More senior researchers often claimed to have a deeper knowledge of the policies under investigation, but this did not mean they had a detailed knowledge of the academic literature on their subject.

\section{Engaging Academics and Experts}

Though researchers in centrist and more generalist think-tanks often lack the requisite knowledge of a subject area, this does not mean they approach experts in the manner of a student (i.e. to learn). Rather, engagement with experts is seen as 'intelligence gathering'. The proverbial student takes time to gain a solid grounding, and follows proper and established learning processes to become an accredited expert. The think-tank researcher bypasses these channels. The detail and recognition of the academic community is not so much needed, rather, think-tank professionals must be sufficiently 'tapped in' to know the current debate and the key issues surrounding it. The value of the academic to the think-tank is the ability to fill in any gaps in the think-tank researcher's wider knowledge of the policy area. This is how think-tanks express their power and influence in the network, picking the experts to draw upon, to build a knowledge base around an idea they think will 'sell'. As a research director at a centrist think-tank explained:

We do this work because we care about the issues. Of course I want to take in as much as I can; I want to know what people are saying but I know at the end of the day I am writing an argument. I won't be saying "here is what these people say, here is what these people say"

Most think-tank researchers use face-to-face conversations with academics they have sought out through online and literature searches. Alongside this, interviewees would note 
how certain ideas, datasets, or findings would be 'cherry-picked' to help bolster the specific findings which would support a think-tank's position.

Even if think-tanks consult established academics, the relative lack of participation in the process by these academics reduces their power and influence over the final product. For example, one centre left think-tank produced a report which was co-authored by a researcher from their organisation and a renowned British social policy academic. Though the authors' names are broadly given equivalence, discussions with the academic drew out that they "just wrote one chapter", and did not recognise any of the names in the acknowledgements section. Established academics can act as the legitimating symbol, bringing credibility and generating interest in the project. However, with limited editorial participation, the document could (and regularly does) develop in directions they might have never envisaged.

The above highlights the somewhat 'journalistic' process of think-tank research; these 'pragmatic ideologists' weave arguments and ideas from a number of embodied and inscribed sources to produce something new and more 'useful' to policymakers. As such, Freeman (2007) characterises policy workers as social learners. Drawing on Lévi-Strauss' notion of the bricoleur, Freeman stresses that policy workers do not confront knowledge like an authoritative intellectual. Instead, they acquire discrete knowledge products from a variety of sites, all partially validated by other authorities. The policy worker, as bricoleur, stores these products and, responding to the changing environment, deploys and applies them at an appropriate moment (Freeman 2007, pp. 485-488). This approach chimes with the think-tank researcher's professed relationship with knowledge and knowledge production. Though they are not, and never will be, expert producers of knowledge, they are not passive recipients of ideas from more established professions. They are not just picking up the best ideas and working solutions; they are translating these ideas into specific ideological narratives, and re-packaging them to become more amenable, given the wider policy context. This is similar to the professional curation Maybin (2016) observed within the British Civil Service. Maybin likens this activity to March and Simon's (1958, p. 165) notion of 'uncertainty absorption' as, the policy worker presents interpretations rather than primary sources in an attempt to deflect external criticisms (Maybin 2016, p. 102).

Though markedly different in their aims, the following think-tanks - small policy-advocacy, all new right, and all evaluation focussed/academic think-tanks - share key similarities. In these organisations, researchers (or report authors) are usually experts in the field they are writing about. This is clearly the case with think-tanks aligned to with the academic field. Conversely, more political/advocacy think-tanks tend to act as platforms for established and notable individuals to make interventions in the public sphere. Such individuals are not 'overnight experts' (Maybin 2014, pp. 80-81), as they hold specialist knowledge, they are experts in the more traditional sense.

Most think-tanks have associates and fellows, and they all engage external authors and researchers to contribute to their publications. For the smaller, more political think-tanks, fellows are often the dominant producers of reports. For these smaller think-tanks, the networks of fellows have a practical use. First, it is cheaper to consult, or sometimes employ, people for specific projects, than to employ (and thus fundraise for) full time permanent staff members. Secondly, networks of fellows free up core staff time to engage in the policy entrepreneurial side of their intellectual labour (Cornford 1990 , pp. 24-25), whereby they push ideas in front of the right people and try to make the terms of debate favourable to their ideas (Denham and Garnett 1998a, b). Thirdly, fellows and external authors often have personal or long-term professional relationships with think-tanks which reduces the risk of policy reports which contradict the organisational brand. 


\section{Enrolling Policy Professionals and Practitioners}

For politically focussed think-tanks from across the ideological spectrum, producing the right expertise (namely well-researched or academic knowledge) is just one of the significant components of a policy report. Other ingredients include the opinion and knowledge of policy professionals, such as Special Advisors (SPADS), ${ }^{4}$ civil servants, and other practitioners from the worlds of campaigning or service delivery.

\section{Policy Professionals}

With regard to SPADs and civil servants, these links are vital for think-tanks to gauge government or party thinking on an issue. Especially for organisations attempting to influence current government, it is vital to know whether officials are already thinking about an issue or if they might endorse it at a later date. The importance of making current research future-focussed was raised by several interviewees. There is an acceptance that ideas should not be too cautious or bound by the perceived needs of the political party which is currently in ascendance. For example, as one researcher explained, obviously they wanted to influence the incumbent minister, but they knew that the minister was not likely to change their agenda. However, researchers were aware that civil servants around the Minister are likely to have a longer tenure in office, being non-political appointments. Secondly, this researcher noted how parties will also seek new ideas periodically, and that ideas articulated to, but ignored by, the current government and opposition can later take on new meaning and importance. Think-tank researchers have a loose notion of what civil servants and politicians may want a few years down the line and use this as the basis for developing research ideas. As one senior researcher observed, "you're always thinking one year ahead".

Researchers would also explain how links to civil service and political advisors are needed to 'peer review' any policy recommendations, and to check that all relevant political or legal issues have been embedded into the narrative. For example, a researcher recounted that, whilst they considered many of the relevant policy proposals from interest groups, wider academic literature, and had an expert committee overseeing the project, they did not know a specific and vital piece of information regarding the legislation. As a researcher from a centrist think-tank explained sometimes this can only be unearthed through direct contact within the relevant government department:

Often we have one contact who refers us to the appropriate person in the department; through them I found out that it was not possible to transfer [mentions specific topic] under EU commission rules and directives. Now I would not have had the foggiest about that had I not spoken to that person. So often we check policy and our workings out with civil servants...that ensures rigour and robustness in our work before we publish it - "is it something which could possibly happen?"

This emic analysis of the learning process highlights two points. The first is the level of detail associated with being a 'policy wonk', which differentiates the think-tank researcher from the scholar or even the concerned layperson. Without access to this particular piece of information, the researcher may have made impractical recommendations. This highlights a

\footnotetext{
${ }^{4}$ A Special Advisor is a political appointee who works with a minister. Unlike permanent civil servants, special advisors resign when parties change office. See Gay (2013) for an official review of the development, definition and role of this position; see also Yong and Hazell (2014).
} 
danger generalist policy advocacy think-tanks face. By staying too focussed on the insights of one community, the knowledge being developed is potentially worthless. Having contacts within the Civil Service affords researchers with access to sounding boards, individuals with much more detailed technical knowledge who can help assess whether an idea is 'possible enough' and consistent with the dominant policy paradigm (Hall 1993).

\section{Investing in Professionals}

Unlike interactions with academics, meetings with practitioners and policy professionals are not simply information-seeking exercises. They are also potential sites of information-sharing and influencing the agenda of other organisations. As one centrist think-tank director notes:

...you're kind of sharing the things that other people are saying and you're sort of stimulating the conversation. Even if you're in that sort of evidence gathering mode, where you're sort of saying to [practitioners] "Hey, tell us what you're doing". The very process is face to face conversation [...] there is all dialogue around that, the way you're framing the questions. [It is] both evidence gathering, but it's also kind of pushing, a bit, it is in itself moving the debate forward and moving people's practice forward because it's making them think about what they do and how they might do it differently...Because one of the other things you're trying to do is creating coalitions.... So when you're taking evidence and someone's saying "where are you on this, what's the problem? What's your funding gap? What are you going to do about that?" It's not just, that's about us learning, but I think it's also about facilitating a process.

Think-tank researchers are already mitigating risks to their credibility during the early evidence gathering stage of the research process. In talking to interested stakeholders, the researcher is asking questions designed to steer the policy debate, ensure they are remembered, and to build coalitions and communities during the research process, so that the audience is primed and ready to receive the product.

\section{Network as a Site of Danger}

So far, this paper has presented the networks within the space of think-tanks through the lens of resource-seeking and allocation. This could be construed as presenting the think-tank at the centre of a web in which its researchers have the autonomy to pick and choose their research topics and connections in line with their organisational goals and ideological commitments. This risks presenting think-tank research as a triumphalist endeavour. Though relationships might be initiated by the think-tank researcher, this does not mean they are free to discipline all the networks they work within. This is clear when we focus on how think-tank research is funded.

\section{Funding and Intellectual Credibility}

Funding, and the manner by which it is raised and disclosed, is vital to an organisation's credibility. In some respects, this echoes the concerns of the consultants studied by Prince (2014). These researchers-for-hire feared that a client would ask them to conduct analysis 
which reached a conclusion that would impinge upon, or conflict with, their desire for objectivity. Think-tanks have a slightly similar, but crucially different concern:

$[\mathrm{O}] \mathrm{n}$ very big political issues, actually having a funder you need to keep happy could potentially be a problem [...] Ideally I would have liked to have had more of a budget for the project than I did, but at least I didn't have to worry about having a consultancy firm, or whatever, [worrying] about what we are concluding.

The prime concern is not with the objectivity of think-tank researchers, but with the independence of their ideas. Within the sample of interviewees, unlike their academic and evaluation-focussed cousins, researchers in political advocacy think-tanks are not primarily concerned with constructing what Jasanoff (2011) describes as the 'view from nowhere', which is associated with the objective gaze of the scientist. Importantly, neither is the researcher concerned with offering the demotic and common sense 'view from everywhere'. All interviewees shared the same means of mitigating these threats to independence posed by funders. From the start of a project, it is made clear to external funders that the think-tank holds editorial control; projects are only pursued on this basis.

\section{Funders' Interests}

Interviewees gave three core reasons as to why groups would wish to fund policy research. These can be summarised under the headings: lobbying, strategy/market advantage, and enlightenment. Lobbying can involve 'employing' a think-tank to propound policy arguments which enable them to influence policy/legislation. No interviewee mentioned any of their reports as being funded with a view to lobbying for or against a specific law or policy.

There are several potential reasons for this. The first may be related to 'interviewee desirability'; given the internalised norms and values around credibility and independence, we would not expect interviewees to openly admit when they felt 'a line had been crossed' between independent research and lobbying, even if they had experienced it. Secondly, funders seeking to influence legislation will often approach a think-tank in the earlier stages of policy development. At this stage, there is still space to shape the terms of debate, and it is not yet clear whether the funder's interests will be positively or negatively impacted by future legislation changes. Thus, funders seek to influence, through funding think-tanks, the climate of opinion in these early stages. Other means of influence, rather than funding think-tanks, will likely be used later on in the policy cycle, when they wish to impact a specific bill (Zetter 2008, pp. 3, 21). Finally, interviewees also suggested that some funders have a genuine interest in public policy research, or insights which can be used to inform organisational or sector specific issues. This does not mean that the research is given without an agenda, but that there are several.

Thirdly, think-tanks obtain value if they can produce interventions which seem broad in interest, or at least when their views are seen as a distinct yet credible third party endorsement to a proffered position on a policy issue. This means that funders will come to a think-tank for issues of wider strategy. Interviewees define this notion in various ways. Sometimes a funder wants to be viewed as a 'thought leader' in a policy area or as 'active in the space'. These wishes have less to do with specific legislation and more to do with broader policy goals, which might impinge on the funder's economic interests. In some cases, this might mean a project with little direct relevance to a funder (perhaps 
particularly a corporate one) is supported simply as a means to have their brand continuously mentioned within the sector. Interviewees described this as part of a wider PR strategy for a corporate brand. For example, funding a series on localism and greater autonomy for councils might not have a direct relationship to a company's short-term business plan, but in the long term it allows the company to display a wider commitment to the sector, which would be one element of their marketing strategy for their services. As one senior researcher noted:

People sponsor bits of work for two reasons. One, if they just want to be seen to active in public affairs. That does happen. The other is that it is connected in some way, loosely 'cause you don't want to lose your credibility, but it is in some way connected to an area which is not running counter to their interests. Now I mean that in a very loose sense [...] For example, we are now doing a project for [large national company]. Now [large national company] don't have a view on the exact policy but if you are [that company] and someone is setting up regional networks which need to share data it makes sense you have an interest. Now we are not going to write anything which promotes [large company A]. They know what we want to explore, they know what we want to say, they know how it fits with our aims and their interests. There is no conflict.

The more sceptical reader might question the veracity of this description, and they would be right to. However, it is noticeable that the above portrayal of the funder/ think-tank relationship fits well with the model of a fruitful lobbying and PR campaign advocated by the distinguished lobbyist Leonal Zetter. For Zetter (2008), a funder should only approach a think-tank that "is sufficiently respected" so that "the study will still carry weight", and they feel confident "that the end result will bolster [the funder's] case. That is usually just a matter of choosing a think-tank which occupies the appropriate position on the political spectrum and agreeing the broad parameters in advance" (Zetter 2008, pp. 46-47).

For example, a researcher at an academic think-tank explained the life of an atypical project which, rather than being sponsored by an established scientific funder or research council, was funded by a large and well known multinational firm. The interviewee noted that, for their organisation, though the analysis and style of report was broadly typical, the funding was not. The interviewee recounted how the use of private sector funding was viewed with a level of surprise, but not outright hostility. When asked about how working with a private firm differed to their usual funder relationships with research councils and government department, the researcher claimed that:

It's hard to say. In terms of hand holding or trying to influence our practice I'd say it was pretty negligible. Nothing at all - I was as free on that project as with any other. But you have to remember these guys are clever; they are too clever to come in all guns blazing or to demand we do $\mathrm{X}, \mathrm{Y}$ and $\mathrm{Z}$ or suppress this or that. That would do them no favours.

Interviewer: So it's in advance, before you even start?

Yes, they have set the terms way in advance; before we had come to it they set the question which sets some form of parameters. Once you engage with that you are 
already in line with their agenda in some way. But I was free to come to my own conclusions within that agenda. So you tell me, is that independent or compromised?

The above account echoes Hillyard et al. (2004) and Smith (2010) who all support the notion that the tendering process is a mode of 'disciplining' policy research. Individual freedom to pursue certain avenues or make specific proposals persists, but the power of the funder is imprinted in the bounding of the research into specific commissioning criteria.

A funder's attempt to shape or control the outcome of a research project is not always so 'hands off', as one Research Fellow from a Centre left think-tank recalled:

[There was a] constant argument over drafts. So I wrote in the draft that "this allocation of funding is inadequate". [Big Four accountancy firm] would comeback with "some would say that it is an inadequate form of allocation". I remember looking at that sentence and going. "No not some would say! We can argue about the sentence at length later but I'm not giving an opinion! If you want to gain insights and make [policy] better, you have to say this is not a good way of doing it!" Intense debates.

In these cases, the funder is attempting to undermine, or humble, the researcher's epistemic authority. Seeking to change words to a more neutral form can be seen as a form of agnotology, which is well documented in the wider literature on think-tanks and lobbying (Dunlap and Jacques 2013; Miller and Dinan 2015). However, unlike the various instances of corporate spin, the above example suggests that there is agency on both sides.

Such intense debates were not the preserve of private sector funders and political advocacy think-tanks. Such debates and posturing were also mentioned by researchers in more academic and evaluation focussed think-tanks with their clients in central government departments. Interviewees would often assert that there is always some form of pressure from the funder and some level of negotiation. This is the basis of commissioned research; all clients, including central government clients, have strategies to try and influence the findings. One strategy requires the think-tank be:

[...] bombarded with questions "like is there more evidence for that?", "can you really claim that?" You know - demanding evidence. Also asking the emphasis to be changed in some way obviously. Now we went through three or four rounds of comments to get the right wording that we were happy with and they were happy with.

As such, it is important to note that the tensions between funders and think-tanks apply equally to policymakers and civil servants in government, as they do to corporate and other interested funders, even though the 'intellectual generosity' of think-tanks means they are willing to relinquish, and indeed actively push, their intellectual products into the hands of these civil servants. Medvetz (2012) defines this as 'intellectual generosity'; unlike closed professions or academic knowledge production, a think-tank researcher will hold a very light ownership over their products.

There are two key differences between the intellectual generosity Medvetz describes and the contractual relationship shared by evaluation focussed think-tanks and their funders. First, this is a process of production rather than dissemination; negotiations over the eventual wording and content of the report are where the individual researcher will feel pressured. Notably, none of these professionals were concerned about the use of the final packaged product. Secondly, within a contractual relationship it is vital to assert oneself by positioning 
the intervention through scholarly credentials to maintain credibility. Think-tanks must position the value and 'reality' of their academic expertise against the interests of any funder to assert an appropriate degree of control over their findings.

\section{Conclusion}

In contrast to previous studies of think-tanks, this paper set out to investigate the process of knowledge production and the networks British think-tank researchers use when producing policy interventions. Rather than concentrating on a specific organisational type, or on a clique of think-tanks within a particular political project, this paper explored how think-tank researchers, from across the ideological and organisational spectrum, engage with the various professions and actors who constitute the policy-research nexus. In so doing, this article also explored how think-tanks construct and manage their expertise, and it presented an account of intellectual life beyond the tired tropes of intellectual subservience and independence.

\section{Brands and Intellectual Credibility}

By focussing on the personal networks of think-tank researchers, this paper suggests that intellectual credibility relies on consistency with a think-tank's brand. These brands vary in their rigidity, and some organisations have more freedom to be flexible with their interpretation of core values. Each brand is specific to an organisation. The brand reflects the general ideological affinities of think-tank as well as its approach to policy research (more advocacy focussed than policy formulating, more media focussed than analytical and so on).

\section{Networks as 'Partial Connections'}

The analysis then focussed on three significant types of actors that think-tank researchers engage in the research process: experts/academics, policy professionals/practitioners, and funders. The enrolment of these different actors was presented as a process akin to Callon's (1986) description of translation. With each interaction, the think-tank researcher attempts to negotiate and enlist the interests of various alters from across fields, in congruence with the think-tank's brand. This suggests that knowledge, ideas, or resources do not simply flow through the relationships that structure this network. Rather, there is constant negotiation between the think-tank researcher and other interested parties in the production (and dissemination) of ideas.

Unlike Callon's notion of translation, which assumes that networks are structured around the acceptance of a central actor's interests, the think-tank researcher relies on fluctuating levels of interest (e.g. to gain money and an audience) and disinterest (e.g. not being led by the funder, not being critiqued by more expert actors, and so on). Thus, they are constantly challenged to maintain their position on the periphery of more established communities. This description of network formation offers a novel perspective on think-tank networks - they are not simply dense ties to one field or a specific coalition. The ties think-tanks form are more like 'partial connections' (Meyer 2008, 2010). Networks do not simply facilitate access or exclusion like we find in 'social capital' models (Bourdieu 1986; Lin et al. 2001) and neither do these networks seek to bind the think-tank researcher to any specific field of profession. Rather these partial connections enable the researcher to use their network to link up with other more stable, credentialed, and arguably more powerful groups, without being locked in or out of any single community. It is this marginality which enables and ensures intellectual credibility. 


\section{Spaces of Negotiation and Prescription}

A key aim of this special edition is to understand how organisational contexts and spaces relate to knowledge production. This paper turns this aim around and suggests that focussing on the production of knowledge also offers a novel perspective on the liminal space inhabited by think-tanks.

The space of think-tanks and policy research is interstitial. Its borders are under-defined and fuzzy. This paper has described how partners in the research process come with their own agendas, levels of engagement, and endowments of social, cultural, and economic capital. In this context, think-tank researchers cannot dictate to theirnetworks. As one think-tank director explained policy research "[...] is a bit of a dance [...] it can be a complicated dance at some points and there are grey areas" (Director, Centreist 1). The same moves, steps and rhythms will not apply to all partners, and at times it might be hard to tell who is leading whom. This process at best aims to 'soften up' actors (be they funders, experts or practitioners) rather than control them. As such, the act of research is as much (if not more) about the deployment of "rhetorical and discursive [strategies] which enhance the political potency of an idea" (Stone 1996, p. 136) than communicating, bridging or repackaging existing knowledge.

This process highlights that neither the think-tank researcher, nor the professions they engage, possess any a priori or explicit control over their network. Drawing on the work of Murdoch (1998, 2006), I suggest that think-tank networks are more accurately describe as 'spaces of negotiation' than 'spaces of prescription'. Spaces of prescription relate to networks with a powerful and a central node that is able to regulate the conduct, activities, and transactions of all other nodes. In spaces of negotiation, interactions are not dominated by one node. Rather, a number of nodes will negotiate positions, actions, and exchanges (Murdoch 1998, pp. 362-363). The network approach adopted in this study enables us to view the space of think-tanks not as a static boundary or meeting place between fields, but as a space which is full of micro struggles based on the interactions that constitute a number of cross-professional networks.

In conclusion, the topography of the space of think-tanks is decentralised, ill-defined and never seems to solidify (Eyal 2013; Murdoch 2006, p. 79; Stampnitzky 2013b). This paper recounts how, when making knowledge products, think-tank researchers need to prime their audiences as best they can to receive their products, because no one can own or control the network in this space between fields. The description of the communications and interactions within a personal network of a think-tank researcher suggests that certain relationships are more problematic to the establishment of credibility, and the negotiation process can place greater power in the hand of some actors within the network and at different phases of the process. However, the way in which this power negotiation unravels, and its impact on intellectual credibility is far from being preordained.

Open Access This article is distributed under the terms of the Creative Commons Attribution 4.0 International License (http://creativecommons.org/licenses/by/4.0/), which permits unrestricted use, distribution, and reproduction in any medium, provided you give appropriate credit to the original author(s) and the source, provide a link to the Creative Commons license, and indicate if changes were made.

\section{References}

Arnoldi, J. (2007). Informational ideas. Thesis Eleven, 89(1), 58-73. https://doi.org/10.1177/0725513607076133. Baert, P. (2012). Positioning theory and intellectual interventions. Journal for the Theory of Social Behaviour, 42 (3), 304-324. https://doi.org/10.1111/j.1468-5914.2012.00492.x.

Ball, S. J., \& Exley, S. (2010). Making policy with 'good ideas': policy networks and the 'intellectuals' of new labour. Journal of Education Policy, 25(2), 151-169. https://doi.org/10.1080/02680930903486125. 
Bentham, J. (2006). The IPPR and demos: think tanks of the new social democracy. The Political Quarterly, 77 (2), 166-174. https://doi.org/10.1111/j.1467-923X.2006.00759.x.

Blank, R. C. (2003). From Thatcher to the third way: think-tanks, intellectuals and the Blair-Projekt. Stuttgart: Ibidem-Verlag.

Boeije, H. (2002). A purposeful approach to the constant comparative method in the analysis of qualitative interviews. Social Sciences, 36(4), 391-409. https://doi.org/10.1023/A:1020909529486.

Bourdieu, P. (1986). The forms of capital. In J. G. Richardson (Ed.), Handbook of theory and research for the sociology of education. New York: Greenwood Press.

Burris, V. (1992). Elite policy-planning networks in the United States. Research in Politics and Society, 4, 111-134.

Burris, V. (2008). The interlock structure of the policy-planning network and the right turn in U.S. state policy. Research in Political Sociology, 17, 3-42. https://doi.org/10.1016/S0895-9935(08)17002-4.

Callon, M. (1986). Some elements of a sociology of translation: domestication of the scallops and the fishermen of St Brieuc Bay. In J. Law (Ed.), Power, action and belief: a new sociology of knowledge? (pp. 196-223). London; Boston: Routledge \& Kegan Paul Books.

Cockett, R. (1994). Thinking the unthinkable: think-tanks and the economic counter-revolution 1931-1983. London: HarperCollins.

Collins, R. (1998). The sociology of philosophies: a global theory of intellectual change. Cambridge: Belknap Press of Harvard University Press.

Cornford, J. (1990). Performing fleas: reflections from a think tank. Policy Studies, 11(4), 22-30. https://doi. org/10.1080/01442879008423579.

Denham, A. (1996). Think-tanks of the New Right. Aldershot: Dartmouth.

Denham, A., \& Garnett, M. (1998a). British think-tanks and the climate of opinion. London: UCL Press.

Denham, A., \& Garnett, M. (1998b). Think tanks, British Politics and the "climate of opinion.". In D. Stone, A. Denham, \& M. Garnett (Eds.), Think tanks across nations: a comparative approach. Manchester: Manchester University Press.

Desai, R. (1994). Second-hand dealers in ideas: think-tanks and Thatcherite hegemony. New Left Review, 203, $27-64$.

Domhoff, G. W. (2006). Who rules America?: power and politics, and social change (5th ed.). Boston: McGraw-Hill.

Dunlap, R. E., \& Jacques, P. J. (2013). Climate change denial books and conservative think tanks exploring the connection. American Behavioral Scientist, 57(6), 699-731. https://doi.org/10.1177/0002764213477096.

Epstein, S. (1995). The construction of lay expertise: AIDS activism and the forging of credibility in the reform of clinical trials. Science, Technology, \& Human Values, 20(4), 408-437.

Eyal, G. (2002). Dangerous liaisons between military intelligence and middle eastern studies in Israel. Theory and Society, 31(5), 653-693.

Eyal, G. (2011). Spaces between fields. In P. Gorski (Ed.), Pierre Bourdieu and historical analysis. Durham: Duke University Press.

Eyal, G. (2013). For a sociology of expertise: the social origins of the autism epidemic. American Journal of Sociology, 118(4), 863-907. https://doi.org/10.1086/668448.

Eyal, G., \& Pok, G. (2011). From a sociology of professions to a sociology of expertise. Presented at the The CAST workshop on security expertise, University of Copenhagen. Retrieved from http://cast.ku.dk/papers security_expertise/Eyal_2011_From_a_sociology_of_professions_to_a_sociology_of_expertise.pdf/.

Eyal, G., \& Pok, G. (2015). What is security expertise? In T. V. Berling \& C. Bueger (Eds.), Security expertise: Practice, power, responsibility (pp. 37-59). Abingdon, UK: Routledge.

Freeman, R. (2007). Epistemological Bricolage: how practitioners make sense of learning. Administration \& Society, 39(4), 476-496. https://doi.org/10.1177/0095399707301857.

Gamble, A. (1988). The free economy and the strong state: the politics of Thatcherism (1988th ed.). Basingstoke: Palgrave Macmillan.

Gay, O. (2013). Special advisers (Commons Library Standard Note No. SN03813). London, United Kingdom: House of Commons Library, Parliament and Constitution Centre. Retrieved from http://www.parliament. uk/briefing-papers/SN03813/special-advisers.

Gibbons, M., Limoges, C., Nowotny, H., Schwartzman, S., Scott, P., \& Trow, M. (1994). The new production of knowledge: the dynamics of science and research in contemporary societies. London: Sage.

Grundmann, R. (2017). The problem of expertise in knowledge societies. Minerva, 55(1), 25-48. https://doi. org/10.1007/s11024-016-9308-7.

Hall, P. A. (1993). Policy paradigms, social learning, and the state: the case of economic policymaking in Britain. Comparative Politics, 25(3), 275. https://doi.org/10.2307/422246.

Harrison, B. (1994). Mrs Thatcher and the intellectuals. Twentieth Century British History, 5(2), 206-245. https://doi.org/10.1093/tcbh/5.2.206.

Helm, T., \& Hope, C. (2008). The top twelve think tanks in Britain. The Daily Telegraph. Retrieved from http:/www.telegraph.co.uk/news/politics/1576447/The-top-twelve-think-tanks-in-Britain.html. 
Hessels, L. K., \& van Lente, H. (2008). Re-thinking new knowledge production: a literature review and a research agenda. Research Policy, 37(4), 740-760. https://doi.org/10.1016/j.respol.2008.01.008.

Hillyard, P., Sim, J., Tombs, S., \& Whyte, D. (2004). Leaving a 'stain upon the silence' contemporary criminology and the politics of dissent. British Journal of Criminology, 44(3), 369-390. https://doi. org/10.1093/bjc/azh024.

Jasanoff, S. (2011). The practices of objectivity in regulatory science. In C. Camic, N. Gross, \& M. Lamont (Eds.), Social knowledge in the making (p. 307). Chicago: University of Chicago Press.

Lin, N., Cook, K. S., \& Burt, R. S. (2001). Social capital: theory and research. New York: Aldine de Gruyter.

March, J. G., \& Simon, H. A. (1958). Organizations. New York: Wiley.

Maybin, J. (2014). "We know who to talk to": embodied knowledge in England's Department of Health. In R. Freeman \& S. Sturdy (Eds.), Knowledge in policy: embodied, inscribed, enacted. Bristol: Policy Press.

Maybin, J. (2016). Producing Health Policy: Knowledge and Knowing in Government Policy Work. London: Palgrave Macmillan.

McClenaghan, M. (2012). Big banks and think-tanks. The Bureau of Investigative Journalism. Retrieved from http://www.thebureauinvestigates.com/2012/07/12/big-banks-and-thinktanks/.

McGann, J. (2017). 2016 global go to think tank index report. TTCSP global go to think tank index reports. Retrieved from http://repository.upenn.edu/think tanks/12.

McGann, J., \& Sabatini, R. (2010). Global Think Tanks: Policy Networks and Governance. Abingdon, UK: Routledge

McLevey, J. (2015). Understanding policy research in liminal spaces: think tank responses to diverging principles of legitimacy. Social Studies of Science, 45(2), 270-293. https://doi.org/10.1177/0306312715575054.

Medvetz, T. (2010). "Public policy is like having a vaudeville act": languages of duty and difference among think tankaffiliated policy experts. Qualitative Sociology, 33(4), 549-562. https://doi.org/10.1007/s11133-010-9166-9.

Medvetz, T. (2012). Think tanks in America: power, politics, and the new forms of intellectual engagement. Chicago: University of Chicago Press.

Meyer, M. (2008). On the boundaries and partial connections between amateurs and professionals. Museums and Society, 6(1), 38-54.

Meyer, M. (2010). Caring for weak ties - the Natural History Museum as a place of encounter between amateur and professional science. Sociological Research Online, 15(3), 9.

Miller, D., \& Dinan, W. (2015). Resisting meaningful action on climate change: think tanks, "merchants of doubt" and the "corporate capture" of sustainable development. In A. Hansen \& R. Cox (Eds.), The Routledge handbook of environment and communication. London: Routledge.

Murdoch, J. (1998). The spaces of actor-network theory. Geoforum, 29(4), 357-374. https://doi.org/10.1016 /S0016-7185(98)00011-6.

Murdoch, J. (2006). Post-structuralist geography: a guide to relational space. London: SAGE.

Nowotny, H., Scott, P., \& Gibbons, M. (2001). Re-thinking science: knowledge and the public in an age of uncertainty. Cambridge: Polity.

Nowotny, H., Scott, P., \& Gibbons, M. (2003). Introduction: 'mode 2' revisited: the new production of knowledge. Minerva, 41(3), 179-194. https://doi.org/10.1023/A:1025505528250.

Osborne, T. (2004). On mediators: intellectuals and the ideas trade in the knowledge society. Economy and Society, 33(4), 430-447. https://doi.org/10.1080/0308514042000285224.

Pautz, H. (2012). Think-tanks, social democracy and social policy. Basingstoke: Palgrave Macmillan.

Pautz, H. (2013). The Think Tanks behind 'Cameronism.'. The British Journal of Politics \& International Relations, 15(3), 362-377. https://doi.org/10.1111/j.1467-856X.2012.00518.x.

Pirie, M. (2012). Think tank: the story of the Adam Smith Institute. London: Biteback,.

Prince, R. (2014). Calculative cultural expertise? Consultants and politics in the UK cultural sector. Sociology, 48 (4), 747-762. https://doi.org/10.1177/0038038513502132.

Ruane, S. (2010). Corporate and political strategy in relation to the private finance initiative in the UK. Critical Social Policy, 30(4), 519-540. https://doi.org/10.1177/0261018310376801.

Salas-Porras, A. (2015). Think Tanks as Key Spaces of the Global Structure of Power. Presented at the Sunbelt XXXV: International Sunbelt Social Network Conference (June 23rd - 28th, 2015), Brighton, UK: INSNA.

Smith, K. (2010). Research, policy and funding — academic treadmills and the squeeze on intellectual spaces. The British Journal of Sociology, 61(1), 176-195. https://doi.org/10.1111/j.1468-4446.2009.01307.x .

Stampnitzky, L. (2011). Disciplining an unruly field: terrorism experts and theories of scientific/intellectual production. Qualitative Sociology, 34(1), 1-19. https://doi.org/10.1007/s11133-010-9187-4.

Stampnitzky, L. (2013a). Disciplining terror: how experts invented "Terrorism.". Cambridge: Cambridge University Press.

Stampnitzky, L. (2013b). Experts, États et théorie des champs. Sociologie de l'expertise en matière de terrorisme. Critique Internationale, 59(2), 89-104. 
Stone, D. (1991). Old guard versus new partisans: think tanks in transition. Australian Journal of Political Science, 26(2), 197-215. https://doi.org/10.1080/00323269108402146.

Stone, D. (1996). Capturing the political imagination: think tanks and the policy process. London, UK: Frank Cass.

Stone, D. (2007). Recycling bins, garbage cans or think tanks? Three myths regarding policy analysis institutes. Public Administration, 85(2), 259-278. https://doi.org/10.1111/j.1467-9299.2007.00649.x.

Stone, D., \& Denham, A. (2004). Think Tank Traditions: Policy Research and the Politics of Ideas. Manchester, UK: Manchester University Press.

Stone, D., Denham, A., \& Garnett, M. (Eds.). (1998). Think tanks across nations: a comparative approach. Manchester, UK: Manchester University Press.

List of thinktanks in the UK. (2013, September 30). The Guardian. Retrieved from https://www.theguardian. com/politics/2013/sep/30/list-thinktanks-uk

Weaver, R. K. (1989). The changing world of think tanks. PS: Political Science and Politics, $22(3), 563$. https://doi.org/10.2307/419623.

Yong, B., \& Hazell, R. (2014). Special advisers: who they are, what they do and why they matter. Oxford: Hart Publishing.

Zetter, L. (2008). Lobbying: the art of political persuasion. Petersfield: Harriman House. 